\title{
平成 23 年東北地方太平洋沖地震津波における 利根川下流の津波遡上再現計算 \\ THE NUMERICAL SIMULATION OF RUNUP TSUNAMI IN TONE RIVER CAUSED BY THE 2011 OFF THE PACIFIC COAST OF TOHOKU EARTHQUAKE
}

\author{
赤穗 良輔 $^{1}$ ·石川 忠晴 ${ }^{2}$ \\ Ryosuke AKOH and Tadaharu ISHIKAWA \\ 1 正会員 工博 東京工業大学 環境理工学創造専攻 ( $7226-8502$ 横浜市緑区長津田町 4259 番) \\ 2 フェロー会員 工博 東京工業大学 環境理工学創造専攻 ( $\bar{T} 226-8502$ 横浜市緑区長津田町 4259 番)
}

\begin{abstract}
This paper presents numerical simulation results for the run-up Tsunami in Tone River caused by the 2011 off the Pacific coast of Tohoku Earthquake. 2-dimensional shallow water equations are solved with unstructured triangular meshes which can express the shore topography smoother and in more detail. Calculation scheme is based on a cell centered finite volume method using modified Roe's approximate Riemann solver which can handle the moving wet/dry fronts correctly. The simulation results are verified by time series of water surface level measured at some water gauge stations located in the river as well as data collected by survey of flooding trace after the Tsunami. Propagation and deformation characteristics of the tsunami waves are discussed in detail by the results of numerical simulation.
\end{abstract}

Key Words: The 2011 off the Pacific coast of Tohoku Earthquake, Tsunami, Tone river, Shallow water systems, Finite volume method, Triangular mesh, Wet/dry fronts

\section{1. 序論}

平成 23 年 3 月 11 日に想定外の規模で発生した東北 地方太平洋沖地震津波以降, 従来の津波対策について 再検討を余儀なくされている.特に被災地域の復旧・復 興計画の策定等を支援する為，津波シミュレーション の重要性が非常に高まっている. 国土交通省より”津波 浸水シミュレーションの手引き1)”が発表され, 被災し た沿岸地域を始めとして津波シミュレーションが実施 されている.

現在用いられている津波シミュレーターは，二次元 浅水流方程式を基礎方程式とした非定常平面二次元モ デルより構築されている.特に 2004 年 12 月のスマト ラ沖地震津波以降, TUNAMI-N2 などの直交構造格子 を用いた津波シミュレーションが数多く行われており， 最高水位について沿岸における痕跡調査結果と概ね一 致する結果が得られている ${ }^{2)}$.

しかし一方で, 河川の樣に湾曲や分合流を含む領域 における津波計算への導入は格子生成の制約上難しく， また, シミュレーションに対する検証用のデータも少 なかったため, 結果の信憑性まで踏み込んだ研究はあ まり多くない . 折敷らによる昭和 58 年日本海中部地震 津波における米代川の津波遡上の再現計算 ${ }^{3)}$ では, 痕 跡値との比較は行われているものの, 到達時刻に関す る情報が非常に少ないため詳細な検討が行われていな
い. 弚のため, 浸水高および到達時刻共に非常に多く のデータが得られた今回の津波について再現計算を行 い, 結果の信憑性を示すことは津波対策計画へのシミュ レーション導入を検討する上で非常に重要である．

また, 近年は浅水流方程式に対する離散化手法につ いて, 数多くの研究が行われている ${ }^{4,5)}$. 特に, (1) 双 曲型法定期系を特性線に沿った波動方程式 (常微分方 程式）系に分解し，これらの波動方程式に対して離散 化を行う”特性曲線法”の採用，(2) 流束と河床勾配項の バランス (C-Property) の保持性，(3) 水域/陸域境界線の 取扱いの三点は, 計算結果の精度に大きな影響を与え ることか指摘されている．より効果的な津波対策を行 うには，これらを考慮した離散化手法を導入した津波 シミュレーターを用いる必要がある。

以上の樣な背景を踏まえ, 本研究では, 複杂隹地形で の津波計算に有効な三角形格子における有限体積法を 用いた平成 23 年東北地方太平洋沖地震津波における利 根川下流の津波遡上再現計算を行う．離散化手法には 先に示した三点を考慮したモデルを採用した . また, 痕 跡調査結果に加えて利根川各所で計測された水位の時 間変動データと比較することで, 浸水高および水位の 時間変動の再現性について検証する．

なお, 本研究で用いる津波痕跡は, ”東北地方太平洋 沖地震津波合同調査グループ”によって行われた調査結 果の速報値 (http://www.coastal.jp/ttjt，2011 年9月 27 日 


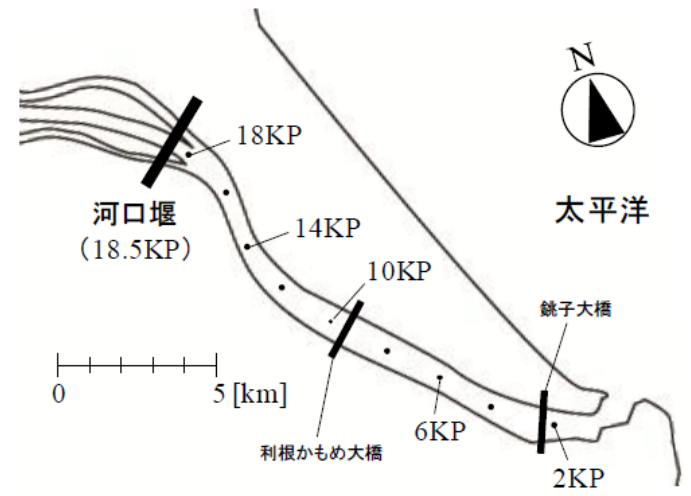

図-1 利根川下流域の平面図

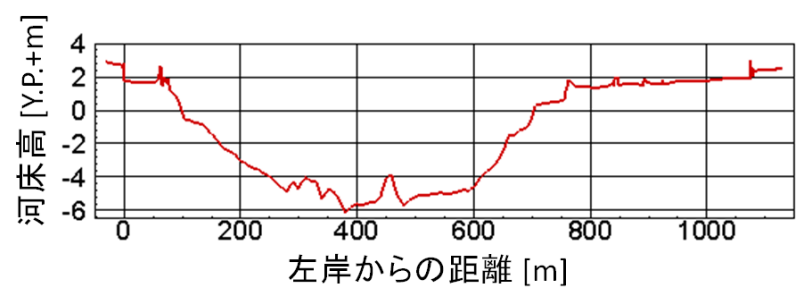

図-2 代表的な横断方向断面図 (6KP)

参照)および田中らによる速報值を活用した ${ }^{6,7)}$.

\section{2. 利根川下流水域における津波解析}

\section{(1) 利根川下流水域の諸言}

図-1に利根川下流水域の平面図を示す . 図中の゙ KP” は河口からの縦断距離を示しており，18.5KP の位置に 河口堰力建設されている.河道は概ね直線的で , 大きな 蛇行部はない，図-2に代表的な断面を示す．なお，地 形デー夕は国土交通省に提供して頂いた，堤防法線間 距離は約 $1,000 \mathrm{~m}$ ，低水路は幅約 $800 \mathrm{~m}$ ，水深約 $5 \mathrm{~m}$ の 典型的複断面である.なお河床勾配は 1 万分の 1 以下 でほぼ水平である。

\section{(2) 数值計算モデル}

\section{a) 支配方程式}

本研究では, 二次元浅水流方程式に基づく数值計算 モデルを用いて解析を行う. 具体的には, 保存変数 $q=$ $[h, M, N]^{T}$, 流束 $F(q), G(q)$, Source 項 $S$ とおくと,

$$
\partial_{t} q+\partial_{x} F(q)+\partial_{y} G(q)=S
$$

$$
F=\left[\begin{array}{c}
M \\
\frac{M^{2}}{h}+\frac{g h^{2}}{2} \\
\frac{M N}{h}
\end{array}\right], G=\left[\begin{array}{c}
N \\
\frac{M N}{h} \\
\frac{N^{2}}{h}+\frac{g h^{2}}{2}
\end{array}\right], S=\left[\begin{array}{c}
0 \\
S_{b x}+S_{f x} \\
S_{b y}+S_{f y}
\end{array}\right]
$$

となる .ここで, $h$ は水深 $, M, N$ は $x, y$ 方向の平均線 流量, $g$ は重力加速度である .また $, S_{b x}, S_{b y}$ は河床勾 配項, $S_{f x}, S_{f y}$ は外力項であり，㫕れ光れ次式より与え
られる。

$$
\begin{aligned}
& S_{b x}=-g h \partial_{x} z, S_{b y}=-g h \partial_{y} z, \\
& S_{f x}=-\frac{\tau_{b x}}{\rho}+\partial_{x}\left(h \tau_{u u}\right)+\partial_{y}\left(h \tau_{u v}\right)+f_{c x}, \\
& S_{f y}=-\frac{\tau_{b y}}{\rho}+\partial_{x}\left(h \tau_{u v}\right)+\partial_{y}\left(h \tau_{v v}\right)+f_{c y}
\end{aligned}
$$

ただし,$z$ は河床高,$\rho$ は水の密度である . また $, \tau_{b x}, \tau_{b y}$ は底面せん断応力， $\tau_{u u}, \tau_{u v}, \tau_{v v}$ は平均流に対し水深平均

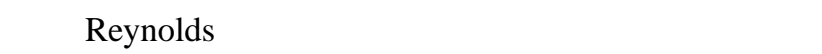
れ Manning 式 , 0 方程式モデルより与える.更に $f_{c x}, f_{c y}$ は地球自転に起因するコリオリカを表す．

\section{b) 離散化手法}

先に記述した理由から本解析には三角形格子におけ る有限体積法, 特に双曲型方程式である浅水流方程式 に有効な Godunov 系統の計算手法を採用する . 本手法 は, 特性線に沿って波動方程式を分解し, 波の風上方 向を考慮した定式化を行うことができる．なお，ここ では具体的な時間発展式のみを記載するに留める．本 手法の詳細については, 文献 ${ }^{8)}$ 等を参照にされたい .

式 (1) を積分することで得られる次式を用いて，各セ ルにおける保存変数の積分平均值 $q_{i}$ を時間発展させる .

$$
q_{i}^{n+1}=q_{i}^{n}-\frac{\Delta t}{\Delta s_{i}}\left(\sum_{j=1}^{3}\left(\boldsymbol{E}_{j}^{*} \cdot \boldsymbol{n} d l_{j}-\Delta s_{i} \boldsymbol{S}_{j}^{*}\right)\right)_{i}^{n}+\Delta t \boldsymbol{S}_{i}^{n}
$$

ここで, $\boldsymbol{E}_{j}^{*}=(\boldsymbol{F}, \boldsymbol{G})_{j}^{*}$ は数值流束テンソル, $\boldsymbol{n}_{j}=$ $\left(n_{x}, n_{y}\right)_{j}$ は各境界の外向き単位法線ベクトル, $\boldsymbol{S}_{\boldsymbol{b}}^{*}=$ $\sum_{j=1}^{3} \boldsymbol{S}_{\boldsymbol{b}}{ }_{j}, \boldsymbol{S}_{f}^{*}$ は光れ艺れ Source 項のセル積分值を示し ている. 本論文では, 数值流束は Roe の近似 Riemann 解法を用いて次式より評価する。

$$
\boldsymbol{E}^{*} \cdot \boldsymbol{n}=\frac{1}{2}\left[\boldsymbol{E}_{R} \cdot \boldsymbol{n}+\boldsymbol{E}_{L} \cdot \boldsymbol{n}-\boldsymbol{R}|\boldsymbol{\Lambda}| \boldsymbol{R}^{-1}\left(q_{R}-q_{L}\right)\right],
$$

$\boldsymbol{R}$ はヤコビアン $A=\partial E(q) / \partial q$ の右固有行列 , $\Lambda$ は固有 值入を対角成分に，他は 0 となる行列である。

また，河床勾配項についても数值流束と同樣に風上 を考慮して以下のように離散化を行うことで, 静止状 態 $(h+z=$ const, $M=N=0)$ において数值流束とバラ ンスすることができ, 非物理的な数值振動が生じない 定式化となる

$$
\boldsymbol{S}_{b_{j}^{*}}^{*}=\boldsymbol{R}\left(\boldsymbol{I}-|\boldsymbol{\Lambda}| \Lambda^{-1}\right) \boldsymbol{R}^{-1} \boldsymbol{S}_{\boldsymbol{b}_{j}}
$$

$I$ は単位行列を表し，また $S_{b}$ は次式より与える .

$$
\boldsymbol{S}_{\boldsymbol{b}}=\left[0,-g \frac{h_{L}+h_{R}}{2} \Delta z \cdot n_{x},-g \frac{h_{L}+h_{R}}{2} \Delta z \cdot n_{y}\right]^{T}
$$

ただし， $\Delta z=\left(z_{R}-z_{L}\right)$ とする.

c) 遡上計算

本研究では, 陸域/水域の移動境界手法として計算格 子を固定した Euler 的手法を用いる。ここでは，Castro によって提案された手法 ${ }^{4)}$ を採用した . 本手法は, 陸 域まで含めて計算格子を作成し，水際に隣接するセル 


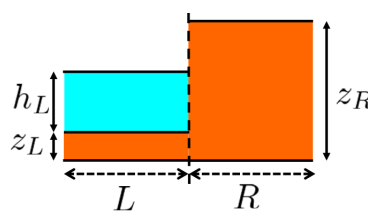

(a)水際境界

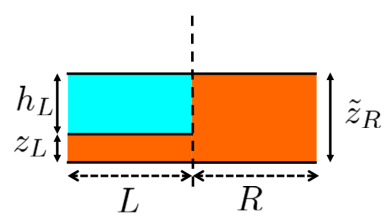

(b)地形の再定義
図-3 水際セル境界における特殊操作の概念図

において以下に示す特殊操作をすることで, 式 (3)-(6) で示した時間発展式を弚のまま適用することできる．

まず，陸域/水域の判定水深 $\varepsilon$ を設定し， $h \leq \varepsilon$ のセル を陸域， $h>\varepsilon$ のセルを水域と光れ定義する．陸域 セルの保存変数は全て 0 とする . また, 陸域と水域の 接するセル境界を水際とする.今 ，図-3(a) に示すよう な左のセルが水域, 右のセルが陸域である水際のセル 境界を考える.この時，光のまま $z_{R}, z_{L}$ を用いて式 (5) より河床勾配項を求めると数值流束とバランスが崩れ てしまい，非物理的な流出入が生じてしまう．乥こで， 図-3(b) の樣に，水際に接する陸域セルにおいて以下の 樣な疑似的な河床高 $\tilde{z}_{R}$ の再定義を行う.

$$
\tilde{z}_{R}= \begin{cases}h_{L}+z_{L} & \text { if } h_{L}+z_{L}<z_{R} \\ z_{R} & \text { otherwise }\end{cases}
$$

式 (7) を用いて河床勾配 $\Delta z=\tilde{z}_{R}-z_{L}$ を与えることで水 際においても数值流束とバランスした定式化を行うこ とができる.更に, 水際に接する水域セルの保存変数 を $\tilde{q}_{i}^{n}=\left[h_{i}^{n}, 0,0\right]^{T}$ として, 式 (4) より数值流束を求める ことで, 水域から陸域へ遡上しない場合は, 水際境界 を壁境界として計算することが可能となる．

\section{(3) 計算条件}

\section{a) 津波解析の概要}

本論文では, 計算コストを抑えるために以下の手順 に従って, 利根川下流域における津波解析を行った .

まず，図-4に示す震源域〜房総沖を含む領域 A にお いて比較的粗い計算格子を設置し, 波源からの津波計 算を行うことで, 利根川河口における水位・流量を算 出する . なお, 図-4 の左下に示す利根川周辺の地形コ ンター図から分かるように, 領域 $\mathrm{A}$ においても解像度 は低いものの利根川が含まれている .

次に，図-5 に示す利根川河口 (-1KP) から河口堰 (18.5KP) までの領域 B に対してより細かい計算格子 を設置し，河口となる断面 (a) に上記の水位・流量を境 界条件として与えて再現計算を行うことで, 河道内に おける津波の再現性について詳細に検証を行う．

具体的には，領域 $A, B$ 共に計算格子は全て三角形と し，領域 A の計算格子のサイズは海域て約 75000m，沿 岸で約 $500 \mathrm{~m}$ ，利根川および陸域では約 $50 \mathrm{~m}$ に設定し た。また領域 B は全域で約 $10 \mathrm{~m}$ と設定した。なお，本 論文では, 特に指定しない限り図に記載された座標軸 はIX系平面直角座標系を用いている.

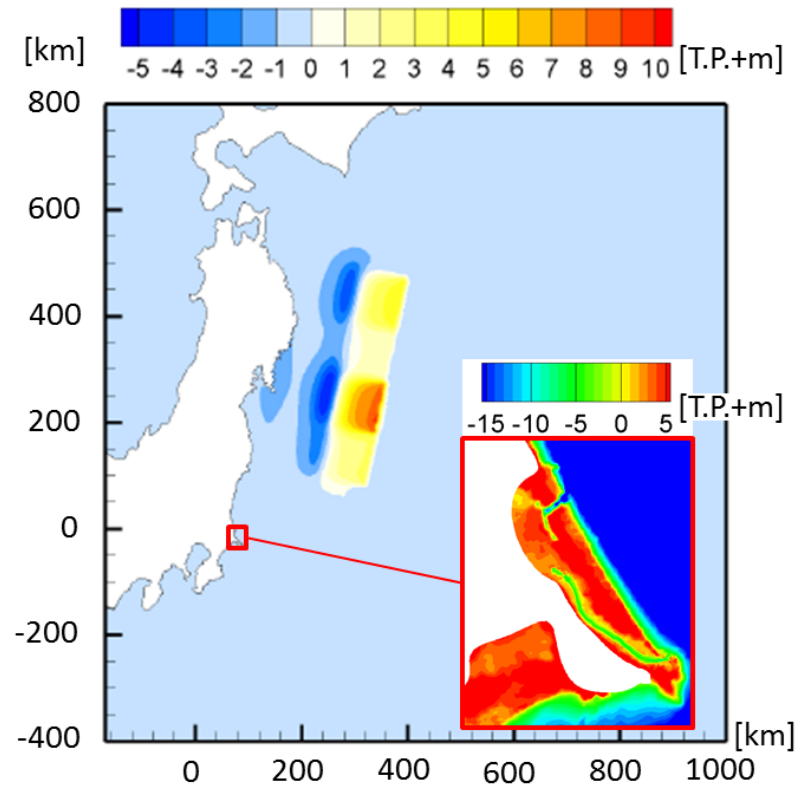

図-4 領域 A の初期水位および利根川周辺の地形図

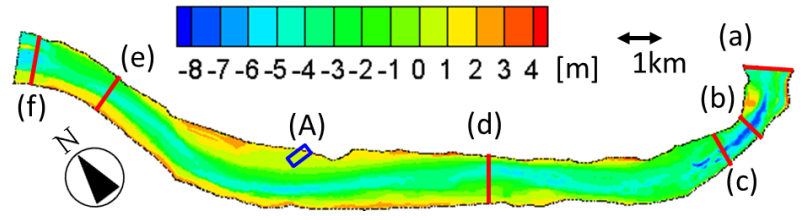

図-5 領域 B の河床地形：(a) 河口 (-1.0KP), (b) 銚子 (0.76KP), (c) 波崎 (1.5KP), (d) 荒波 (7.0KP), (e) 太田 新田 (16.5KP), (f) 河口堰下 (18.0KP)

また, 文献 ${ }^{9)} よ り 6$ 分程度で岩手県沖から茨城県沖 の三か所が順次変動したことから，3月 11 日 14 時 52 分を本解析の初期時刻とし, 計算時間間隔を $0.1[\mathrm{~s}]$ に設 定して 3 時間後まで計算を行った.更に，陸域/水域の 判定水位を $\varepsilon=1.0 e-6[\mathrm{~m}]$ とした .ただし，微小水深 領域では非常に大きな流速が発生し計算が不安定にな るため, $h<0.05[\mathrm{~m}]$ の計算セルでは流速 0 と設定した . b) 初期条件

まず領域 A については, 初期波形に東北地方太平洋 沖地震の断層モデル (東北大学モデル (version1.0)) ${ }^{10)}$ を 採用し，Manshnha\&Smylie の方法 ${ }^{11)}$ により地震に伴う 海底地盤変位量を計算する。また, 潮位は時間変動を 考慮せず， 3 月 11 日の 14 時と 15 時の利根川河口水位 12) より内挿した地震発生時の河口水位 T.P.- $0.49 \mathrm{~m}$ と設 定し, 海底地盤変位量と潮位の合計を初期水位として 与えた . 領域 A の初期水位のコンター図を図-4 に示す . 次に領域 B については，3月 11 日 13:00〜15:00 まで の堰流量および河口水位 ${ }^{12)}$ を境界条件とした助走計算 を行い，得られた結果を初期条件として与えた。なお， 再現計算では河口堰を壁境界として与えた 。

c) 地形条件

領域 A については, 文献 ${ }^{1)}$ に基づき JTOPO30((財) 日本水路協会)，J-EGG500(日本海洋データセンター), M7000 シリーズ ((財) 日本水路協会)より作成された地 


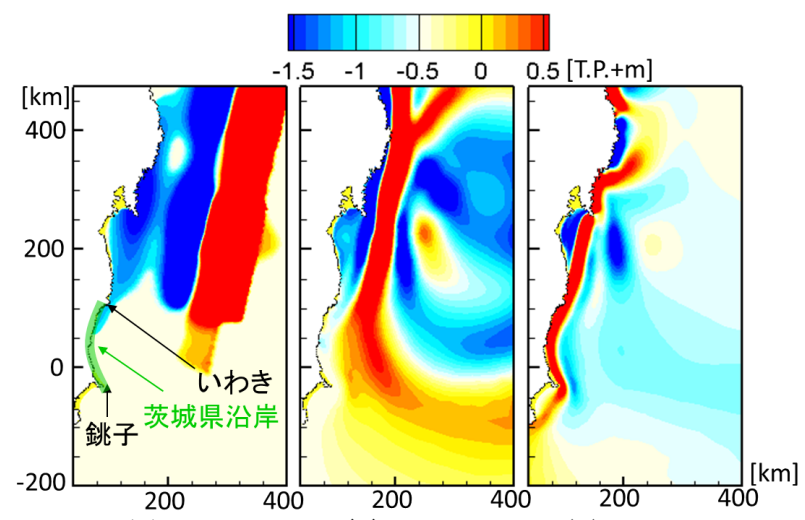

(a) $0 \min$

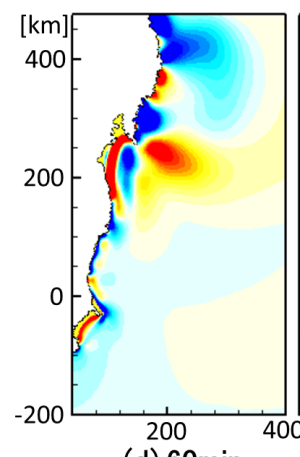

(d) $60 \mathrm{~min}$ (b) $20 \mathrm{~min}$



(e) $80 \mathrm{~min}$ (c) $40 \mathrm{~min}$

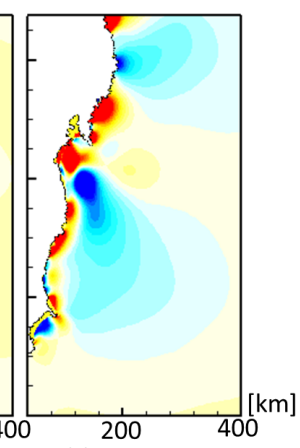

(f) $100 \mathrm{~min}$

図-6 津波伝播の様子 (水位のコンター図)

形データを三角形格子へ内挿した . 粗度係数は文献 ${ }^{1)}$ を参考に全域 0.025 とした .

領域 B については，国土交通省より提供して頂いた $1 \mathrm{~km}$ 間隔の利根川横断地形データおよび利根川下流河 川環境基図 (河床コンター図) ${ }^{13)}$ より内挿した . 利根川 周辺の地形图を図-5に示す. 粗度係数は文献 ${ }^{14)}$ を参考 に低水路を 0.02 ，高水敷を 0.04 とした .なお，領域 $\mathrm{A}$ ， B 共に粗度係数については , 今後の検討の余地がある

\section{3. 再現計算および検証}

\section{(1) 茨城県沿岸における津波最高水位の比較}

図-6に 100 分後までの水位の変動を示す.これらよ り各海岸線における津波は, 第一波は初期波源に起因 するが，第二波以降は周辺の海岸線で反射した波であ ることが見て取れる．茨城県沿岸に到達する第二波以 降の津波は，いわきから銚子にわたる湾曲した海岸線 で反射した第一波により形成されている，光こで，本 論文では銚子での第一波の最高水位が観測結果と一致 するように試行計算を行い, 東北大学モデルの変位量 を 1.7 倍にして計算した結果を用いて議論する．なお， この樣な調整を行った場合，本計算モデルより得られ る東北地方沿岸での最高水位は, 調査結果と比較して 矛盾がないことを確認している．

まず，図-7(a) に茨城県沿岸における最高水位のコン ター図を示す . 今回の津波では, 小名浜港 , 大津港 , 大 洗海岸, 飯岡港といった岬のすぐ南側の海岸において



(a)最高水位コンター図

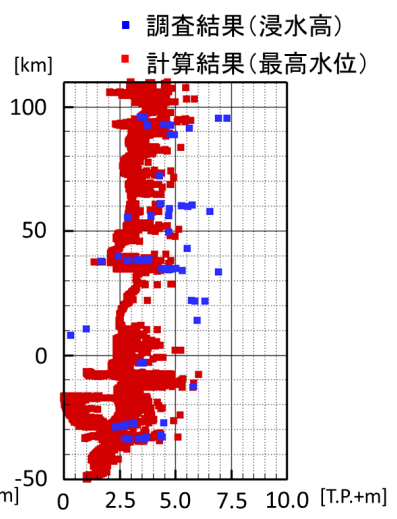

(b)沿岸の最高水位 および浸水高調査結果
図-7 津波最高水位分布図

高くなる傾向か樣々な調査結果から報告されている.再 現計算でもこの樣な傾向が表れており，定性的に良く 一致していることが分かる .

また，図-7(b) に計算結果の最高水位を赤で，浸水高 の調査結果 $\left.{ }^{6}\right)$ を青で示した . (a) と (b) は縦軸を合わせ て記述している.(b)より明らかなように，茨城県沿岸 において両者は概ね一致しており，本初期条件の調整は 茨城県沿岸において定量的に妥当であると考えられる。

(2) 利根川縦断方向の水位の比較

3.(1)で示した領域 $\mathrm{A}$ の計算結果を用いて，領域 $\mathrm{B} の$ 計算を行った . 図-5に示す (a) から (f) の計 6 断面の澪に おける水位の時間変化を図-8 に示す . 赤線か計算結果， 青点が河道内に設置された水位計より得られた観測デー タである . まず，(1) の結果と一致する河口 (a) での水 位について，第一波か計算開始から約 40 分後に到達し， 兴の後第二波が約 90 分後, 第三波が 150 分後に到達 している.第二波は観測データと比較して 15 分程早く なっているが, 第一波, 第三波については非常に良く一 致している.また，第一波が最も高く約 T.P. $+2 \mathrm{~m}$ ，次に 第三波か約 T.P. $+1.5 \mathrm{~m}$ ，最も低い第二波は約 T.P. $+0.5 \mathrm{~m}$ となっており，いずれも観測データとほぼ一致してい る. 更に, 河口より上流の地点である (b)〜 (f) の各位置 においても，水位が観測データよりやや低い箇所が見 受けられるものの，観測データと良く一致しており，非 常に再現性の高い計算結果であることが示された 。

\section{(3) 水際周辺の流況}

図-9に , 図-5 の青枠 (A) の位置における水際境界の 移動および流速べクトルの時間変動の樣子を示す. 図 中の左側が低水路 (水域)，右側が高水敷 (陸域) であ り，赤線が初期水際を示している.また，図の左上側が 上流，右下側が下流である . 水位が上昇するに従って 水際境界が移動し, 高水敷に浸水する流況が再現でき ていることが分かる.河川遡上する津波の樣に波が進 行する方向と平行に水際境界がある場合, 水際周辺の 流速ベクトルは水際に垂直な方向，すなわち水域が広 

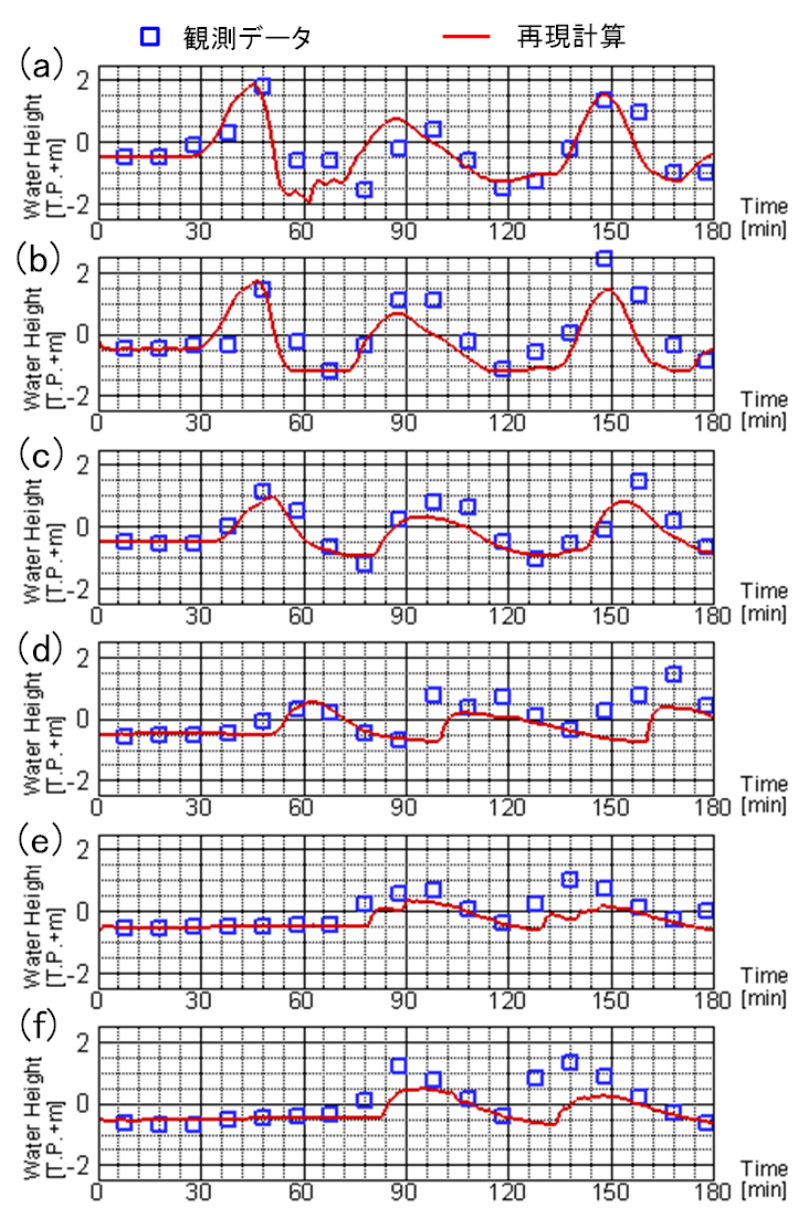

図-8 水位の時間変化の比較 : (a) 河口 (-1.0KP), (b) 銚子 (0.76KP), (c) 波崎 (1.5KP), (d) 荒波 (7.0KP), (e) 太田 新田 (16.5KP), (f) 河口堰下 (18.0KP)

がる方向に向いている. 光して, 浸水領域が広がり水 際から離れるに伴い河道に沿った流速分布となってい ることが分かった .

\section{(4) 縦断方向の水位変動}

続いて，図-10に縦断方向の澪における水位の時間変 動を示す . 先に示したように, 領域 B の河道幅は全域 にわたってほぼ一定であり，またほぼ直線的であるた め，津波の上流側への伝播速度は河道の深さに概ね依存 している . 具体的には，いずれの波も 10 分あたり 6KP より下流側では $4 \mathrm{~km}$ 程度, 上流側では $3 \mathrm{~km}$ 程度の速度 で伝播している樣子が確認できる .

水位についても，河口で最も大きく，伝播するにつ れ徐々に低下しており，湾曲や深堀等の局所的な地形 に依存した水位変化は現れていないことが見て取れる． ただし, 河口堰付近では, 津波が堰き止められている ため水位が高くなっており，また，10KPから $12 \mathrm{KP} に$ おいては，第 2 波と河口堰で反射した第 1 波が合体す る為に水位が高くなっている樣子が確認できる．

\section{(5) 最高水位分布および浸水深分布}

図-11 に最高水位分布, 図-12 に浸水深 (最高水位-河 床高)のコンター図を示す . 具体的な浸水領域としては，

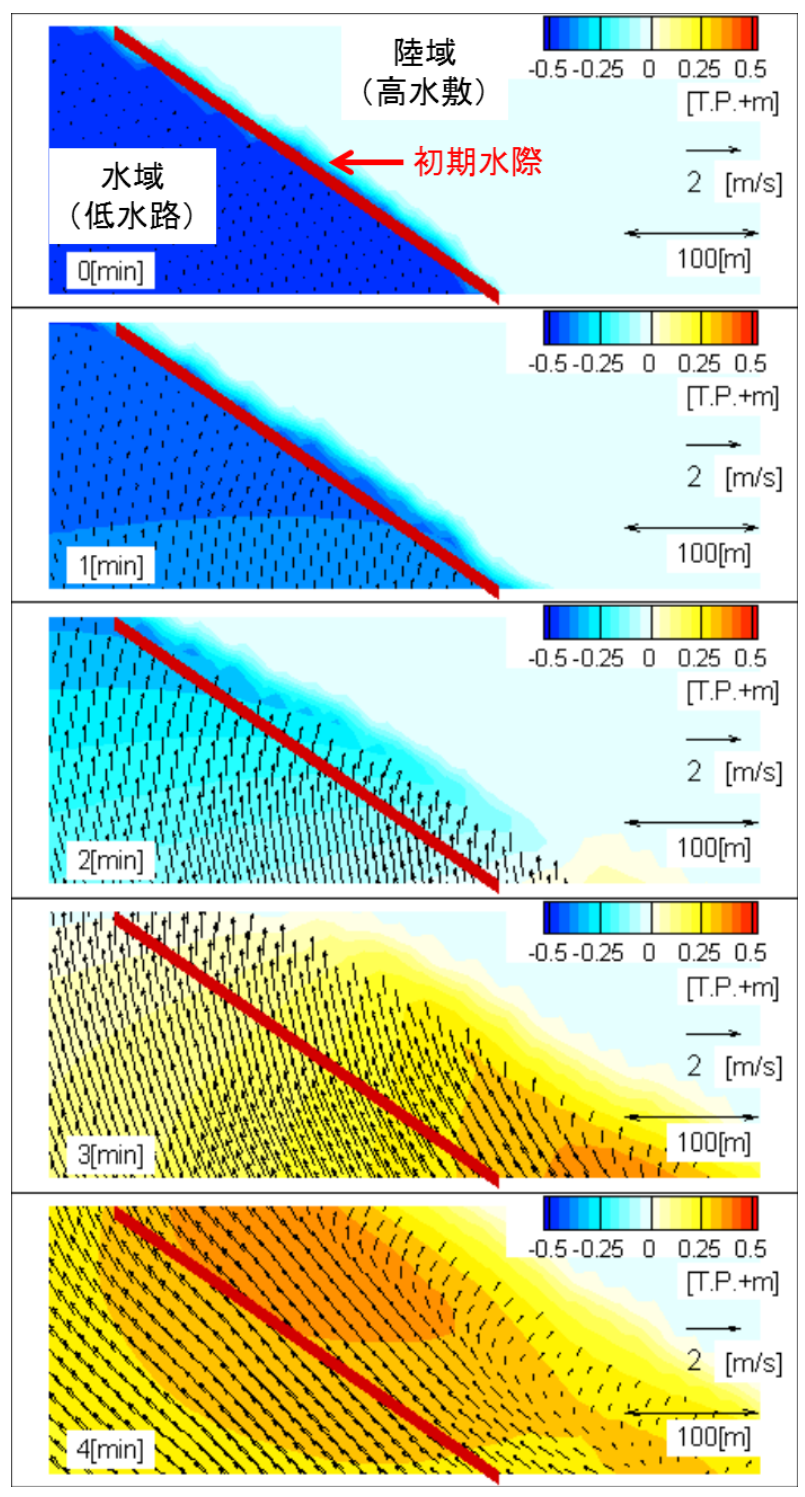

図-9 水際境界の移動と 流速ベクトル変動

(A) 松本町周辺 , (B) 高田川合流地点, (C) 高田町周辺 , (D) 利根川河口堰 (利根川右岸) , (E) 利根川河口堰 (利 根川左岸) が挙げられる .これらの箇所は田中らに報 告された津波痕跡調査 7) でも浸水が確認されている． 図-12 に赤で示した数值は各箇所における痕跡浸水深で あり，平面流況についても概ね良好に再現できている と考えられる .

特に, (C) の周辺では右岸・左岸共に, 下流側よりも 最高水位が大きくなっており，浸水深が $1 \mathrm{~m}$ 以上となっ ている、また，特に左岸側は広い範囲で浸水する結果 が得られた . 今回行った再現計算では, 防波堤等の構 造物に関してはモデルに組み込まれていないため，過 大評価していることも考えらえる．しかし，本領域は 先に示したように，第二波と河口堰で反射した第一波 が衝突する位置であり，また左岸側は比較的低い地形 となっている.更に, 上流の緩やかな湾曲形状から直 線形状へ遷移している箇所である為，湾曲内側となる 左岸側の運動量が高くなり, 結果として第二波と衝突 した際に水位が上昇した可能性が考えられる . 



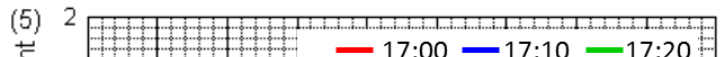


図-10 縦断方向の水位変動

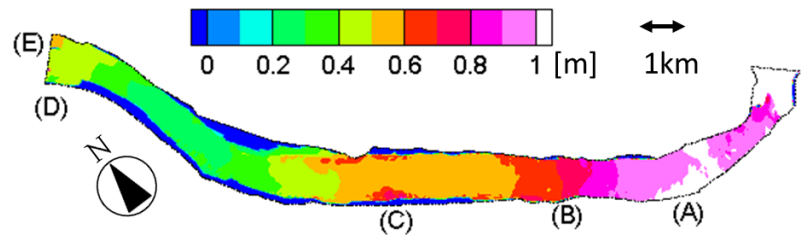

図-11 利根川の最高水位分布



図-12 利根川の浸水深分布

\section{4. 結論と今後の課題}

本論文では, 三角形格子における浅水流計算モデル を用いて, 平成 23 年東北地方太平洋沖地震津波の再現 計算を行った . 得られた結論は以下のとおりである.

1. 東北大学モデル (version 1.0) から得られた初期波 形を調整することで, 茨城県沿岸における津波最 高水位を再現することに成功した．

2. 利根川下流域への遡上津波再現計算を行い，観測 データと比較したところ，水位および到達時刻共 に概ね良好に一致することを確認した .
3. 高水敷への浸水領域について, 再現計算の結果は 痕跡調査の結果と概ね一致していることを示した .

4. $10 \mathrm{KP}$ 付近の高田町周辺において, 第二波と河口堰 で反射した第一波が合体し，周囲と比べてより大 きな最高水位となる可能性を示した .

今後は構造物モデルの導入や, 湾曲部における二次 流を考慮できる準三次元モデルを採用することで, 更 に実用的な再現計算モデルの構築を行う予定である . 謝辞：本研究で用いた諸条件データは東京建設コン サルタント，国土交通省利根川下流河川事務所より提 供して頂きました .ここに記して感謝の意を表します．

\section{参考文献}

1）国土交通省水管理・国土保全局海岸室, 国土交通省国土 技術政策総合研究所河川研究部海岸研究室 (2011): 平成 23 年東北地方太平洋沖地震による津波の対策のための津 波浸水シミュレーションの手引き

2) 藤間 功司, 松本 浩幸, 高橋 智幸, 越村俊一, 富田 孝 史，家村浩和 (2007): インド洋津波からスマトラ沖地震 を分析する, 海岸工学委員会・地震工学委員会・津波被 害推定ならびに軽減技術研究小委員会

3) 折敷秀雄, 千葉周二, 岩瀬浩之, 藤間功司, 松井幸一 (2008): 米代川における 1983 年日本海中部地震津波の再 現計算と解析上の課題, 海岸工学論文集, 第 55 巻, pp.241245.

4) M. J. Castro, A. Ferreiro, J. A. García-Rodríguez, J. M .González-Vida, J. Macías, C. Parés and M. E. VázquezCendón(2005): On the numerical treatment of wet/dry fronts in shallow flows: application to one-layer and twolayer systems, Math. Comp. Mod. 42, pp.419-439.

5) 重枝末玲, 秋山壽一郎, 重岡広美 (2007): ドライ・ウェッ 卜状態となる地形起伏がある場での汇濫流の数值シミュ レーション，水工学論文集, 第 51 巻, pp.781-786.

6) 東北地方太平洋沖地震津波合同調査グループの website:http://www.coastal.jp/ttjt/

7) 田中規夫 , 八木澤順治 (2011): 沿岸部における砂丘・海 岸林が東北地方太平洋沖地震による津波被害軽減に及ぼ した効果〜千葉県北部における被害状況調査結果〜

8) R. J. Leveque(2002): Finite Volume Methods for Hyperbolic Problems, CAMBRIDGE UNIVERSITY PRESS.

9) 気象庁地震予知情報課 (2011): 「平成 23 年 (2011 年) 東 北地方太平洋沖地震」について (第 15 報)

10）今村文彦, 越村俊一, 大家隆行, 馬㴊幸雄, 村嶋陽一 (2011): 東北地方太平洋沖地震を対象とした津波シミュ レーションの実施 東北大学モデル (version1.0), 東北大 学大学院工学研究科 付属災害制御研究センター

11) Mansinha, L., Smylie, D. E.(1971): The Displacement fields of inclined faults, Bulletin of the Seismological Society of America, Vol.61, No.5, pp.1433-1440.

12）独立行政法人水資源機構利根川下流総合管理所利根川河 口堰管理所の website:http://water.go.jp/kanto/tonekako/

13）国土交通省関東地方整備局利根川下流河川事務所，利根 川下流河川環境基図 (平面図ベース)，No.1-6.

14）吉田圭介, 石川忠晴, 箕浦靖久 (2009): 準三次元 CIPSoroban モデルによる利根川洪水流の大規模数值計算， 水工学論文集, 第 53 巻, pp.877-882. 